\title{
EEF1A2 Gene
}

National Cancer Institute

\section{Source}

National Cancer Institute. EEF1A2 Gene. NCI Thesaurus. Code C38582.

This gene is involved in nucleotide binding and protein translation. 